\title{
SERUM COPPER AND ZINC AND THE RISK OF DEATH FROM CANCER AND CARDIOVASCULAR DISEASE
}

\author{
FRANS J. KOK, ${ }^{1}$ CORNELIA M. VAN DUIJN, ${ }^{1,2}$ ALBERT HOFMAN, ${ }^{1}$ \\ GIJSBERT B. VAN DER VOET, ${ }^{3}$ FRED A. DE WOLFF ${ }^{3}$ CLAY H. CH. PAAYS, ${ }^{1}$ \\ AND HANS A. VALKENBURG ${ }^{1}$
}

Kok, F. J. (Dept. of Epidemiology, Erasmus U. Medical School, 3000 DR Rotterdam, The Netherlands), C. M. Van Duijn, A. Hofman, G. B. Van Der Voet, F. A. De Wolff, C. H. Ch. Paays, and H. A. Valkenburg. Serum copper and zinc and the risk of death from cancer and cardiovascular disease. Am J Epidemiol 1988;128:352-9.

To investigate the association of serum copper and zinc with mortality from cancer and cardiovascular disease, the authors performed a case-control analysis of data obtained in a Dutch prospective follow-up study. Cancer $(n=64)$ and cardiovascular disease $(n=62)$ deaths and their matched controls were taken from a cohort of 10,532 persons examined in 1975-1978. Trace elements were measured in baseline serum samples, which had been stored during the six to nine years of follow-up. The adjusted risk of death from cancer and cardiovascular disease was about four times higher for subjects in the highest serum copper quintile (>1.43 $\mathrm{mg} / \mathrm{liter}$ ) compared with those with normal levels. The excess mortality observed in subjects with low copper status suggests a U-shaped relation. No significant change in the risk of death from cancer and cardiovascular disease was found for subjects with low or high baseline levels of serum zinc. However, a protective effect of a high zinc status on the risk of cancer and cardiovascular disease is compatible with the data. For definitive conclusions, analysis of larger prospective data sets is recommended.

cardiovascular diseases; copper; longitudinal studies; neoplasms; zinc

The essential trace elements copper and zinc are implicated in chronic disease etiology. Nutritional or metabolic imbalances may affect the cardiovascular system $(1,2)$ and lipid metabolism (3-7). Associations with cardiovascular disease risk factors, are, however, controversial (8-11). Other effects of copper and zinc are related to oxidative tissue damage. Excess copper catalyzes free radical formation $(12,13)$, whereas marginal copper levels inhibit superoxide dismutase, an enzyme with antioxidant capacity $(14,15)$. Zinc protects against free radical injury (16). Moreover, a low zinc status reduces the potential anticarcinogenic effect of vitamin A (17-19) and may affect immune response $(17,20)$.

Correlation studies $(21,22)$ and casecontrol data $(8,23-26)$, with measurements made after diagnosis of the disease, have
Received for publication December 30, 1986, and in final form October 9, 1987.

${ }^{1}$ Department of Epidemiology, Erasmus University Medical School, Rotterdam, The Netherlands.

${ }^{2}$ Department of Human Nutrition, Agricultural University, Wageningen, The Netherlands.

${ }^{3}$ Department of Toxicology, Academic Hospital, Leiden, The Netherlands.

Reprint requests to Dr. Frans J. Kok at present address: Department of Human Nutrition, TNOCIVO Toxicology and Nutrition Institute, P.O. Box 360, 3700 AJ Zeist, The Netherlands.

This study is supported by the Netherlands Heart Foundation grant 34.013 .

The authors thank Dr. F. N. Groustra for performing the mortality follow-up and Hanny Leezer-de Hoog for technical and administrative assistance. 
shown higher serum copper and lower serum zinc levels in cancer and cardiovascular disease patients. These data are difficult to interpret, however, because the disease may have affected trace element levels. Therefore, in etiologic research a prospective design is favored. In such a study (27), mean baseline serum copper levels were found to be higher in cancer cases than in controls, although not significantly. No differences were observed for serum zinc.

We now report on the relations between serum copper and zinc and the risk of death from cancer and cardiovascular disease in a nine-year prospective follow-up study in the Netherlands. Since experimental data suggest a curvilinear association $(1,4,10$, 12-15), risk analysis for both low and high serum concentrations of these trace elements is presented.

\section{Materials AND Methods}

\section{Study population}

In 1975-1978, a population survey was undertaken in the Dutch town of Zoetermeer to assess the prevalence and determinants of several chronic diseases (28). Zoetermeer is a suburb of the metropolitan area of The Hague, with a population of 60,000 at the time of the survey. All inhabitants of a rural and an urban district of Zoetermeer who were aged five years or more were invited for a medical examination. Of the 13,462 eligible subjects, 10,532 (78 per cent) participated in the survey. At entry into the baseline survey, major chronic disease risk factors (smoking, serum total cholesterol, blood pressure, and body mass index) were measured, and a self-administered questionnaire was completed by each respondent and crosschecked by a research assistant/physician. Venous blood was collected, and a sample of serum was stored at -20 C. Details of this initial study have been published previously (28).

From the municipal register of Zoetermeer, the vital status of 95 per cent of the cohort could be determined. Cause of death was established from death certificates, hospital records, and data provided by the Dutch Central Bureau of Statistics. Classification of deaths that occurred up to December 31, 1983, was made according to a standardized protocol based on International Classification of Diseases, Eighth Revision (ICD-8), guidelines, with the physician unaware of exposure status. During the six- to nine-year follow-up, 360 participants died. Information on cause of death was available for 312 subjects: 114 (37 per cent) died from cancer (ICD- 8 codes 140 239) and 106 (34 per cent) died from cardiovascular disease (ICD-8 codes 390-458). Cancer deaths that occurred in the first year of follow-up ( $n=13)$ were excluded from the analyses, as were subjects with a history of myocardial infarction and/or cerebrovascular disease at baseline $(n=16)$. Statistical analyses were based on 64 cancer deaths and 62 cardiovascular deaths because of incomplete baseline data or unavailable serum samples. The latter was mainly due to other micronutrient analysis in these sera $(29,30)$. The cancer deaths comprised 16 cases of gastrointestinal cancer, 17 cases of respiratory cancer, six of breast cancer, six of leukemia, 12 of urogenital cancer, and seven of cancers of other sites. The cardiovascular deaths comprised 40 cases of coronary heart disease, 10 of cerebrovascular disease, and 12 of other cardiovascular diseases. Each case was paired with two controls, randomly selected from the pool of cohort members still alive on December 31, 1983. Cases and controls were matched according to sex and age (five-year interval). Moreover, cancer cases and their controls were matched for smoking status (current smoker: yes/no; number of cigarettes smoked daily: five or less, 614 , or 15 or more).

\section{Laboratory analyses}

Concentrations of copper and zinc in serum were determined with a model 3030 atomic absorption spectrophotometer (Perkin Elmer BV, Gouda, The Netherlands) 
equipped with an air-acetylene flame burner. A copper hollow cathode lamp was operated at $20 \mathrm{~mA}$ (for zinc, $15 \mathrm{~mA}$ ). Atomic absorption was measured at 324.8 $\mathrm{nm}$ for copper and $213.9 \mathrm{~nm}$ for zinc. The spectral bandwidth was $0.7 \mathrm{~nm}$ (31). Standard solutions containing $0,10,20,30$, and $40 \mu \mathrm{mol} /$ liter of copper $\left(\mathrm{CuSO}_{4} \cdot 5 \mathrm{H}_{2} \mathrm{O}\right)$ or zinc $\left(\mathrm{ZnSO}_{4} \cdot 7 \mathrm{H}_{2} \mathrm{O}\right)$ were prepared in distilled water. All analyses were performed in duplicate. For the copper analysis, coefficients of variation ranged from 3.0 per cent $(1.06 \pm 0.03 \mathrm{mg}$ copper per liter, $n=40)$ to 1.9 per cent $(1.73 \pm 0.03 \mathrm{mg}$ copper per liter, $n=40$ ). For zinc, these values ranged from 15.8 to 4.8 per cent $(0.34 \pm 0.05 \mathrm{mg}$ zinc per liter and $2.73 \pm 0.13 \mathrm{mg}$ zinc per liter, $n=40$ ), respectively. Laboratory procedures for selenium, retinol (vitamin A), and alpha-tocopherol (vitamin E) analyses have been reported elsewhere (30). Blood samples were collected using a disposable syringe and needle (Becton-Dickinson Co., Drogheda, Ireland). After being processed in polystyrene tubes, serum was stored at $-20 \mathrm{C}$ in a polypropylene tube. Samples taken from these tubes did not contain copper and zinc levels above the detection limit of the method used for measuring sera. Therefore, no significant contamination during sampling and storage is likely to have occurred. Sampling, storage, and further handling of the sera of cases and controls have been carried out identically so we expect no bias in comparing laboratory data. Specimens from each case and the matched controls were randomly grouped into triplets, and these groups were analyzed sequentially with the laboratory personnel unaware of disease status.

\section{Data analysis}

First, to estimate the association between serum copper and zinc and mortality from cancer and cardiovascular disease, we compared average values of the trace elements between cases and controls. The pairedsample $t$ test was used to test differences in serum copper, serum zinc, and the ratio of serum copper to serum zinc between cases and the mean value of both controls. Results of statistical testing are expressed as two-tailed $p$ values. Although the distributions of serum copper and zinc were somewhat skewed, the distributions of the test statistics were normal. Multiple regression analysis was used to investigate the association of serum copper and zinc with micronutrients and major risk factors. In this analysis, we used log-transformed copper and zinc distributions. For ease of interpretation, untransformed coefficients are presented. Partial correlation coefficients for copper and zinc levels with micronutrients and major risk factors were also calculated. Second, to study the effect of the trace elements on the risk of death from cancer and cardiovascular disease, conditional multiple logistic regression was used with maximum likelihood estimation of the regression coefficients and their standard errors (32). Relative risks were estimated as odds ratios. The model which was fitted included serum copper and zinc and the potential confounders, i.e., serum cholesterol, systolic and diastolic blood pressures, body mass index, serum antioxidants (selenium, vitamin $\mathrm{A}$, and vitamin $\mathrm{E}$ ), years of education, week of blood collection, and smoking (only for cardiovascular mortality). Effect modification was studied by stratified analysis.

\section{RESUlts}

Baseline characteristics of cancer and cardiovascular disease deaths and their matched controls are shown in table 1 . Mean levels of serum copper tended to be higher in cancer deaths than in controls (difference, 6 per cent; $p=0.08$ ). Cardiovascular deaths did not differ significantly from controls in mean level of serum copper, serum zinc, or the ratio of copper to zinc. The association of serum copper with major chronic disease risk factors and that of serum copper with serum antioxidant levels were not significant. The decrease in serum zinc with age was statistically significant (regression coefficient: $b=-0.0025$, standard error $=0.0009, p=0.02)$. Serum 
zinc was positively associated $(p<0.05)$ with serum total cholesterol, vitamin A, and vitamin $\mathrm{E}$. Zinc and copper were highly intercorrelated (table 2).

For subjects in the highest serum copper quintile $(>1.43 \mathrm{mg} /$ liter $)$, the adjusted relative risk of death from cancer was 3.7 (95 per cent confidence interval $(\mathrm{CI})=1.5-9.1)$ and for cardiovascular death it was 3.5 (95 per cent CI $=1.4-8.7$ ) (tables 3 and 4 ). Although not statistically significant, the increased cancer and cardiovascular risks associated with low serum copper $(<1.05$ $\mathrm{mg} /$ liter) point to the existence of a $\mathrm{U}$ shaped relation. Adding this lowest quintile to the reference category resulted in only minor changes in the risk estimates. The adjusted relative risk for subjects in the highest quintile of the serum copper distribution calculated in this way was 3.0 (95 per cent $\mathrm{CI}=1.3-7.0$ ) for cancer death and 2.8 (95 per cent $\mathrm{CI}=1.2-6.6$ ) for cardiovascular death. Although numbers in the extremes were small, effect modification of serum vitamins $\mathrm{A}$ and $\mathrm{E}$ and selenium on the impact of copper was studied. Crude

TABLE 1

Baseline characteristics of cancer and cardiovascular deaths and their matched controls, Zoetermeer, The Netherlands, 1975-1983

\begin{tabular}{|c|c|c|c|c|}
\hline Baseline characteristics & $\begin{array}{c}\text { Cancer deaths } \\
(n=64)\end{array}$ & $\begin{array}{l}\text { Controls } \\
(n=128)\end{array}$ & $\begin{array}{l}\text { Cardiovascular } \\
\text { disease deaths } \\
(n=62)\end{array}$ & $\begin{array}{l}\text { Controls } \\
(n=124)\end{array}$ \\
\hline \multicolumn{5}{|l|}{ Proportion of } \\
\hline Males ${ }^{\dagger}$ & 56.3 & 56.3 & 53.2 & 53.2 \\
\hline Current smokers ${ }^{\dagger}$ & 37.5 & 37.5 & 33.9 & 31.5 \\
\hline Never smokers & 37.5 & 36.7 & 41.9 & 47.6 \\
\hline \multicolumn{5}{|l|}{ Mean \pm standard deviation of } \\
\hline Age $($ years $) \dagger$ & $59.7 \pm 13.7$ & $59.4 \pm 13.3$ & $68.2 \pm 12.1$ & $67.8 \pm 11.8$ \\
\hline Body mass index $\left(\mathrm{kg} / \mathrm{m}^{2}\right)$ & $25.3 \pm 2.9$ & $25.1 \pm 3.6$ & $26.4 \pm 3.9$ & $25.7 \pm 3.6$ \\
\hline Serum total cholesterol (mg/dl) & $235.5 \pm 44.2$ & $237.3 \pm 41.9$ & $250.7 \pm 42.5$ & $234.0 \pm 38.5^{*}$ \\
\hline Systolic blood pressure $(\mathrm{mmHg})$ & $143.0 \pm 21.8$ & $138.3 \pm 20.4$ & $153.1 \pm 24.0$ & $144.7 \pm 21.1^{*}$ \\
\hline Diastolic blood pressure ( $\mathrm{mmHg}$ ) & $83.1 \pm 12.7$ & $80.2 \pm 11.7$ & $84.3 \pm 13.3$ & $82.5 \pm 13.2$ \\
\hline Cigarettes (no. smoked/day) $\dagger$ & $16.9 \pm 9.5$ & $15.4 \pm 6.7$ & $11.2 \pm 8.4$ & $13.4 \pm 6.5$ \\
\hline Serum copper (mg/liter) & $1.33 \pm 0.38$ & $1.25 \pm 0.28$ & $1.32 \pm 0.31$ & $1.27 \pm 0.27$ \\
\hline Serum zinc (mg/liter) & $0.72 \pm 0.26$ & $0.74 \pm 0.16$ & $0.71 \pm 0.19$ & $0.71 \pm 0.16$ \\
\hline
\end{tabular}

${ }^{*} p<0.05$.

† Matching variables (smoking status only for cancer cases and controls).

TABLE 2

Association of serum copper and zinc with major risk factors and serum micronutrient levels in the total control group ( $n=252$ ), Zoetermeer, The Netherlands, 1975-1983

\begin{tabular}{|c|c|c|c|c|}
\hline \multirow{2}{*}{ Risk factors and micronutrients } & \multicolumn{2}{|c|}{ Serum copper (mg/liter) } & \multicolumn{2}{|c|}{ Serum zinc (mg/liter) } \\
\hline & $b^{+}$ & $r \ddagger$ & $b^{\dagger}$ & $r \ddagger$ \\
\hline Serum total cholesterol (mg/dl) & $18.34(11.71)$ & 0.14 & $46.08^{*}(19.33)$ & $0.21^{*}$ \\
\hline Systolic blood pressure ( $\mathrm{mmHg})$ & $-4.66 \quad(5.86)$ & -0.06 & $-7.15 \quad(9.77)$ & -0.07 \\
\hline Diastolic blood pressure $(\mathrm{mmHg})$ & $-0.15 \quad(3.79)$ & -0.01 & $(6.27)$ & -0.09 \\
\hline Cigarette smoking (no. smoked/day) & $0.75 \quad(1.84)$ & 0.04 & $(3.05)$ & 0.12 \\
\hline \multicolumn{5}{|l|}{ Serum levels of } \\
\hline Copper (mg/liter) & & & $0.42^{*} \quad(0.12)$ & $0.29^{*}$ \\
\hline Selenium $(\mu \mathrm{g} / \mathrm{dl})$ & $-0.90 \quad(0.78)$ & -0.07 & $0.84 \quad(1.31)$ & 0.02 \\
\hline Vitamin $\mathrm{A}(\mu \mathrm{g} / \mathrm{dl})$ & $3.69 \quad(5.01)$ & 0.07 & $31.29^{*} \quad(8.01)$ & $0.32^{*}$ \\
\hline Vitamin E (mg/liter) & $-0.07 \quad(0.80)$ & 0.04 & $3.04^{*} \quad(1.30)$ & $0.20^{*}$ \\
\hline
\end{tabular}

${ }^{*} p<0.05$.

$+b=$ regression coefficient (standard error) adjusted for sex and age.

$\ddagger r=$ partial correlation adjusted for sex and age. 
relative risks of death from cancer or cardiovascular disease for subjects in the highest quintile of serum copper and the lowest quintile of serum vitamin $\mathrm{E}$, serum vitamin $\mathrm{A}$, and serum selenium, respectively, ranged from 1.1 to 3.8. All confidence intervals included 1.0 and had a wide range, indicating no effect modification. For high levels of serum zinc, a protective effect on mortality risk, although not statistically significant, was observed (relative risk = $0.4,95$ per cent $\mathrm{CI}=0.1-1.3$ for cardiovascular mortality (table 4), and relative risk $=0.7,95$ per cent $\mathrm{CI}=0.3-2.0$ for cancer mortality (table 3 )). These effects did not change when the lowest four quintiles were taken as the reference category.

\section{Discussion}

In this prospective study, a strong significant association was observed between high baseline serum copper level and the subsequent risk of death from cancer and cardiovascular disease. Several studies have shown significantly higher serum or tissue copper levels in prevalent cancer (24-26) and cardiovascular disease $(8,24)$ patients compared with healthy controls. Causal interpretation of these data is difficult, however, because the disease might have affected trace element status. Although the present analysis was a more rigorous test of the hypothesis, the possibility that elevated serum copper levels are the result of preclinical disease cannot be completely ruled out. Even our six - to nine-year followup might have been too short for diseases with long induction periods such as cancer and cardiovascular disease. However, we excluded cases with a history of myocardial infarction and/or cerebrovascular disease and those who died in the first year of follow-up. Moreover, after exclusion of deaths that occurred in the subsequent three years of follow-up, only minor changes occurred in the risk estimates. Our

TABLE 3

Risk of death from cancer associated with low or high baseline serum copper and zinc levels, Zoetermeer, The Netherlands, 1975-1983

\begin{tabular}{|c|c|c|c|c|c|}
\hline \multirow{2}{*}{ Quintiles* } & \multirow{2}{*}{$\begin{array}{l}\text { Quintile division } \\
\quad(\mathrm{mg} / \text { liter })\end{array}$} & \multicolumn{2}{|c|}{ No. of } & \multirow{2}{*}{$\begin{array}{l}\text { Adjusted relative } \\
\text { risk }{ }^{\dagger}\end{array}$} & \multirow{2}{*}{$\begin{array}{l}95 \% \text { confidence } \\
\text { interval }\end{array}$} \\
\hline & & Cases & Controls & & \\
\hline \multicolumn{6}{|c|}{ Serum copper } \\
\hline 1 & $<1.05$ & 16 & 27 & 1.8 & $0.7-4.7$ \\
\hline 2 & $1.05-1.16$ & 7 & 25 & & \\
\hline 3 & $1.17-1.25$ & 6 & 26 & $1.0 \ddagger$ & \\
\hline 4 & $1.26-1.43$ & 9 & 25 & & \\
\hline 5 & $>1.43$ & 26 & 25 & 3.7 & $1.5-9.1$ \\
\hline Total & & 64 & 128 & & \\
\hline \multicolumn{6}{|c|}{ Serum zinc } \\
\hline 1 & $<0.62$ & 18 & 26 & 1.4 & $0.5-3.8$ \\
\hline 2 & $0.62-0.70$ & 13 & 23 & & \\
\hline 3 & $0.71-0.78$ & 13 & 26 & $1.0 \ddagger$ & \\
\hline 4 & $0.79-0.86$ & 8 & 26 & & \\
\hline 5 & $>0.86$ & 12 & 27 & 0.7 & $0.3-2.0$ \\
\hline Total & & 64 & 128 & & \\
\hline
\end{tabular}

* Based on distribution among matched controls.

† Adjusted in a conditional regression model for serum total cholesterol, systolic and diastolic blood pressures, body mass index, antioxidants (serum selenium, vitamin A, and vitamin E), years of education, week of blood collection, and serum zinc or serum copper.

$\ddagger$ Reference category, consisting of quintiles 2-4. 
TABLE 4

Risk of death from cardiovascular disease associated with low or high baseline serum copper and zinc levels, Zoetermeer, The Netherlands, 1975-1983

\begin{tabular}{|c|c|c|c|c|c|}
\hline \multirow{2}{*}{ Quintiles* } & \multirow{2}{*}{$\begin{array}{l}\text { Quintile division } \\
\text { (mg/liter) }\end{array}$} & \multicolumn{2}{|c|}{ No. of } & \multirow{2}{*}{$\begin{array}{l}\text { Adjusted relative } \\
\text { risk } \dagger\end{array}$} & \multirow{2}{*}{$\begin{array}{l}95 \% \text { confidence } \\
\text { interval }\end{array}$} \\
\hline & & Cases & Controls & & \\
\hline \multicolumn{6}{|c|}{ Serum copper } \\
\hline 1 & $<1.05$ & 13 & 23 & 2.2 & $0.8-6.4$ \\
\hline 2 & $1.05-1.18$ & 9 & 25 & & \\
\hline 3 & $1.19-1.31$ & 5 & 25 & $1.0 \ddagger$ & \\
\hline 4 & $1.32-1.43$ & 12 & 24 & & \\
\hline 5 & $>1.43$ & 23 & 27 & 3.5 & $1.4-8.7$ \\
\hline Total & & 62 & 124 & & \\
\hline \multicolumn{6}{|c|}{ Serum zinc } \\
\hline 1 & $<0.60$ & 13 & 25 & 0.6 & $0.2-2.0$ \\
\hline 2 & $0.60-0.68$ & 10 & 26 & & \\
\hline 3 & $0.69-0.73$ & 7 & 24 & $1.0 \ddagger$ & \\
\hline 4 & $0.74-0.83$ & 21 & 23 & & \\
\hline 5 & $>0.83$ & 11 & 26 & 0.4 & $0.1-1.3$ \\
\hline Total & & 62 & 124 & & \\
\hline
\end{tabular}

* Based on distribution among matched controls.

$\dagger$ Adjusted in a conditional regression model for smoking, serum total cholesterol, systolic and diastolic blood pressures, body mass index, antioxidants (serum selenium, vitamin A, and vitamin E), years of education, week of blood collection, and serum zinc or serum copper.

$\ddagger$ Reference category, consisting of quintiles $2-4$.

results support those of the only published prospective study so far of which we are aware (27), in which a 7 per cent increase in mean serum copper level was found among cancer cases $(n=26)$ compared with matched controls. Serum samples in that study were taken two years or more before the development of clinically manifest tumors. No risk estimates were given for the extremes of the copper distribution.

In our data, there was no clear evidence for an excess mortality risk for cardiovascular disease and cancer for subjects initially low in serum copper. Risk estimates were strong, however, and the existence of a U-shaped relation is therefore conceivable, particularly for death from cardiovascular disease. Since numbers in the extreme quintiles were small, larger studies are required for definitive conclusions. No subjects had levels below the generally considered lower normal value of serum copper $(0.65 \mathrm{mg} /$ liter $)$, therefore pathologic effects induced by copper deficiency (e.g., cardiomyopathy $(1,2))$ probably did not occur.

For optimal comparison, we matched cases and controls for sex, age, and smoking status and controlled for potential confounding of other risk factors by multivariate modeling. Positive relations have been reported between serum copper concentration and smoking $(8,9)$, and systolic pressure (33). The association with serum total cholesterol is inconsistent $(3,4,9-11)$. Serum copper levels were found to be increased in hyperlipidemic patients with or without atherosclerosis (10). Furthermore, positive relations with serum total cholesterol $(8,9)$ and a negative one with high density lipoprotein cholesterol level have been observed (9). However, some experimental studies found elevated serum cholesterol levels in rats deficient in copper (4). In the analysis, we also adjusted for nutrients with antioxidative capacity (serum selenium, vitamin $\mathrm{E}$, and vitamin 
A) and serum zinc. Some confounding in the risk estimates may still be present because information on vitamin $\mathrm{C}$, iron status, and other nutrients that are associated with copper was not available. Dietary sources rich in copper are nuts, liver, and fish. Milk and milk products contain low concentrations of this trace element. The intake of copper in Dutch adults $(1.5 \mathrm{mg}$ copper per day) is largely determined by the consumption of bread (22 per cent), potatoes (13 per cent), and beverages (12 per cent) (34). In addition to low or high intake of these foods, other life-style habits such as smoking, oral contraceptive use, and metabolic or physiologic conditions such as hypertension and pregnancy may contribute to the copper status.

The role of copper in malignancy and atherosclerosis may be related to its involvement in the biologic damage caused by the superoxide radical. Most of the tissue copper is specifically bound, such as in the superoxide dismutase enzyme. A marginal copper status stimulates peroxidative damage by inhibition of the activity of this enzyme $(14,15)$. However, an excess in total tissue copper resulting in elevated nonspecific bound copper may by itself catalyze free radical formation $(12,13,25)$.

A high concentration of zinc is found in nuts, cereals, and meat, whereas the zinc content of white bread is low. Meat and meat products ( 24 per cent), bread (20 per cent), and milk and milk products (17 per cent) are the major contributors to the daily intake of zinc (13.6 mg zinc per day) in the Netherlands (34).

The mechanisms underlying a lower cancer risk associated with a high serum zinc concentration are hypothetical. It has been suggested that a low serum zinc level reduces the protective effect of vitamin A on cancer incidence, whereas higher levels mediate an optimal utilization of vitamin A $(16,35)$. The significant direct association we found between serum vitamin A concentration and serum zinc is in accordance with this hypothesis and has been reported earlier $(18,19)$. Furthermore, zinc protects against iron- and copper-catalyzed freeradical injury $(16,17)$ and an adequate supply of zinc is essential for normal immune function (20).

The observation by Halsted and Smith (23) of lower plasma zinc levels among prevalent cardiovascular disease cases compared with healthy controls was not confirmed in our prospective data. However, serum zinc tends to fall dramatically after acute tissue injury (36), but it is unclear whether altered zinc has any etiologic relevance for cardiovascular disease.

In conclusion, our results suggest that high serum copper levels and probably also low levels may be associated with increased cancer and cardiovascular disease risk. Although confounding was minimized, the possibility that other factors associated with these trace elements might be responsible for the observed effects cannot be fully ruled out. Larger prospective follow-up studies are needed to confirm our observations, and experimental data may further elucidate the biologic mechanisms.

\section{REFERENCES}

1. Stemmer KL, Petering HG, Murthy L, et al. Copper deficiency effects on cardiovascular system and lipid metabolism in the rat; the role of dietary proteins and excessive zinc. Ann Nutr Metab 1985;29:332-47.

2. Kopp SJ, Klevay LM, Feliksik JM. Physiological and metabolic characterization of a cardiomyopathy induced by chronic copper deficiency. Am J Physiol 1983;245:H855-66.

3. Fischer PWF, Giroux A, Belonje B, et al. The effect of dietary copper and zinc on cholesterol metabolism. Am J Clin Nutr 1980;33:1019-25.

4. Allen KGD, Klevay LM. Cholesterolemia and cardiovascular abnormalities in rats caused by copper deficiency. Atherosclerosis 1978;29:81-93.

5. Woo H, Gibbs DL, Hooper PL, et al. Zinc and lipid metabolism. (Letter.) Am J Clin Nutr 1981; 34:120-1.

6. Koo SI, Ramlet JS. Dietary cholesterol decreases the serum level of zinc: further evidence for the positive relationship between serum zinc and high-density lipoproteins. Am J Clin Nutr 1983; 37:918-23.

7. Hooper PL, Visconti L, Garry PJ, et al. Zinc lowers high-density lipoprotein-cholesterol levels. JAMA 1980;244:1960-1.

8. Manthey J, Stoeppler M, Morgenstern W, et al. Magnesium and trace metals: risk factors for coronary heart disease? Circulation 1981;64:722-9.

9. Kromhout D, Wibowo AAE, Herber RFM, et al. 
Trace metals and coronary heart disease risk indicators in 152 elderly men (The Zutphen Study). Am J Epidemiol 1985;122:378-85.

10. Uza G, Gabor S, Kovats A, et al. Serum zinc and copper in hyperlipoproteinemia. Biol Trace Elements Res 1985;8:167-72.

11. Fischer PWF, Collins MW. Relationship between serum zinc and copper and risk factors associated with cardiovascular disease. (Letter.) Am J Clin Nutr 1981;34:595-7.

12. Samuni A, Chevion M, Czapski G. Unusual copper-induced sensitization of the biological damage due to superoxide radicals. J Biol Chem 1981; 256:12632-5.

13. Harman D. The free radical theory of aging: effect of age on serum copper levels. J Gerontol 1965; 20:151-3.

14. Oberley LW, Buettner GR. Role of superoxide dismutase in cancer: a review. Cancer Res 1979; 38:1141-9.

15. Paynter DI. The role of dietary copper, manganese, selenium, and vitamin $\mathrm{E}$ in lipid peroxidation in tissues of the rat. Biol Trace Elements Res 1980;2:121-35.

16. Burke JP, Fenton MR. Effect of a zinc-deficient diet on lipid peroxidation in liver and tumor subcellular membranes (42083). Proc Soc Exp Biol Med 1985;179:187-91.

17. Prasad AS. Clinical, biochemical and nutritional spectrum of zinc deficiency in human subjects: an update. Nutr Rev 1983;41:197-208.

18. Atukorala S, Basu TK, Dickerson JWT, et al. Vitamin $\mathrm{A}$, zinc and lung cancer. Br $\mathrm{J}$ Cancer 1979;40:927-31.

19. Mellow MH, Layne EA, Lipman TO, et al. Plasma zinc and vitamin $\mathrm{A}$ in human squamous carcinoma of the esophagus. Cancer 1983;51:1615-20.

20. Duchateau J, Delespesse G, Vrijens R, et al. Beneficial effects of oral zinc supplementation on the immune response of old people. Am J Med 1981;70:1001-4.

21. Punsar S, Erametse O, Karvonen MJ, et al. Coronary heart disease and drinking water. J Chronic Dis 1975;28:259-87.

22. Schrauzer GN, White DA, Schneider CJ. Cancer mortality correlation studies. IV. Associations with dietary intakes and blood levels of certain trace elements, notably Se-antagonists. Bioinorg Chem 1977;7:35-56.

23. Halsted JA, Smith JC. Plasma-zinc in health and disease. Lancet 1970;1:322-4.

24. Sullivan JF, Blotcky AJ, Jetton MM, et al. Serum levels of selenium, calcium, copper, magnesium, manganese and zinc in various human diseases. $J$ Nutr 1979;109:1432-7.

25. Margalioth EJ, Schenker JG, Chevion M. Copper and zinc levels in normal and malignant tissues. Cancer 1983;52:868-72.

26. Gorodetsky R, Fuks Z, Sulkes A, et al. Correlation of erythrocyte and plasma levels of zinc, copper, and iron with evidence of metastatic spread in cancer patients. Cancer 1985;55:779-87.

27. Haines AP, Thompson AP, Basu TK, et al. Cancer, retinol binding protein, zinc and copper. Lancet $1982 ; 1: 52-3$.

28. Valkenburg HA, Hofman A, Klein F, et al. An epidemiological study of cardiovascular risk indicators (EPOZ). I. Blood pressure, serum cholesterol level, Quetelet index and smoking habits in an open population aged 5 years and over. Ned Tijdschr Geneeskd 1980;124:183-9.

29. Kok FJ, de Bruijn AM, Hofman A, et al. Is serum selenium a risk factor for cancer in men only? Am J Epidemiol 1987;125:12-16.

30. Kok FJ, de Bruijn AM, Vermeeren R, et al. Serum selenium, vitamin antioxidants and cardiovascular mortality-a 9-year follow-up study in the Netherlands. Am J Clin Nutr 1987;45:462-8.

31. Tsalev DL. Atomic absorption spectrometry in occupational and environmental health practice. Vol II. Boca Raton, FL: CRC Press, Inc., 1984:6573, 215-23.

32. Breslow NE, Day NE. Statistical methods in cancer research. IARC scientific publication no. 32 . Lyon: IARC, 1980.

33. Liu CF, Medeiros DM. Excess diet copper increases systolic blood pressure in rats. Biol Trace Elements Res 1986;9:15-24.

34. Van Dokkum W, De Vos RH, Muys T. Onderzoek van additieven, chemische contaminanten en nutrienten in totale dagvoedingen, 1984-1986. Deel 2. Mineralen en spoorelementen. Report V/A 86.348/330359, CIVO-TNO, Zeist, The Netherlands: Toxicology and Nutrition Institute, 1986.

35. Smith JC, McDaniel EG, Fan FF, et al. Zinc: a trace element essential in vitamin A metabolism. Science 1973;181:954-5.

36. Singh R, Mehrotra MP, Singh MM, et al. Serum zinc in myocardial infarction: diagnostic and prognostic significance. Angiology 1983;34:215-21. 